\title{
偏心荷重が超高強度コンクリートの圧縮強度試験結果に及ぼす影響 INFLUENCE OF ECCENTRIC LOADING ON COMPRESSIVE STRENGTH TEST RESULT OF HIGH STRENGTH CONCRETE
}

\author{
小山善行*, 早川光敬**, 陣内 浩***, 中村光男**** \\ Yoshiyuki KOYAMA, Mitsutaka HAYAKAWA, Hiroshi JINNAI \\ and Mitsuo NAKAMURA
}

\begin{abstract}
This paper deals with the influence of the eccentric loading in the compressive strength test of high-strength concrete. In the experiment, five kinds of concretes (water binder ratio is $65 \%$ to $20 \%$ ) were examined. The range of eccentric distance is $0 \mathrm{~mm}$ to $9 \mathrm{~mm}$. Conclusions are as follows. (1) The influence of eccentric loading becomes large as concrete becomes more high-strength. (2) The experimental result of (1) can be presumed based on vertical strain of specimen. (3) The compressive strength test result in the tolerance level of JIS A 1108(within 1mm) becomes almost equivalent. (4) Under eccentric loading, the horizontal strain of the upper part of specimen became small. This result has suggested increasing the restraint of the upper part of specimen under eccentric loading.
\end{abstract}

Keywords: Eccentric loading, Positioning of test specimen, Compressive Strength, High Strength Concrete 偏心荷重, 供試体の設置位置, 圧縮強度, 超高強度コンクリート

\section{1. はじめに}

昨今，構造物の大型化，大空間化などに伴い，超高強度コンクリ 一トの利用が増加している。このような超高強度コンクリートの圧 縮強度試験を繰り返し行うと, 稀に予想よりも大幅に低い試験結果 が得られてしまうことがある。このような試験結果が得られてしま う原因は一つではなく, 超高強度コンクリートの試験時の留意事項 として様々な要因の影響を明らかにしていくことが重要と考えられ る。

これまで筆者らは，供試体の平面度，荷重速度が高強度コンクリ 一トの圧縮強度試験結果に及ぼす影響に関する実験を行い, いくつ

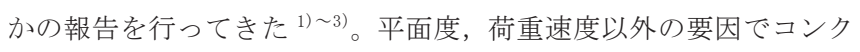
リートの圧縮強度試験に影響を及ぼすものとしては, 試験時の供試 体の設置位置などがあげられる。

供試体が正しい位置に設置されていないことに起因する偏心荷重 の影響を取り上げた研究は, 野口らが 1990 年代に行った一連の研究

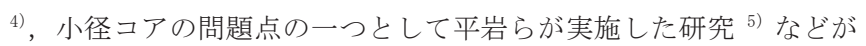
ある。野口らの研究では, 圧縮強度試験結果に与える偏心荷重の影 響を抑制するためには, 潤滑剤として鉱物油の使用が望ましいこと,
球座と供試体が接触した後は回転を固定すべきであることなどが有 効であることが明らかになっている。この成果により，潤滑剂とし て鉱物油を使用するようになった試験機関は増加したものと考えら れるが，すべての試験機関が球座を固定式に交換するほどの設備投 資をするにはまだ時間がかかるものと考えられる。

さらに, 野口らの研究では, 強度レベルが高くなることによって 偏心による圧縮強度の低下が大きくなる理由は，材料的な性質に起 因寸る局部破壊の影響であることが示されている。コンクリートは 高強度化するにつれ脆性的な破壊を示寸ようになるため，この説明 は一つの要因を明らかにしているものと考えられる。しかし，応力 度と縦ひずみの関係がより直線的になる超高強度領域のコンクリー トでは, 野口らの説明に加え，供試体の設置位置の誤差などに起因 する応力度分布の状態なども異なっている可能性がある。

そこで筆者らは, 昨今用いられている圧縮強度 $20 \mathrm{~N} / \mathrm{mm}^{2}$ 程度の普 通強度領域のコンクリートから $180 \mathrm{~N} / \mathrm{mm}^{2}$ 程度の超高強度領域まで のコンクリートに関し，供試体の設置位置の誤差などに起因寸る比 較的小さな偏心が超高強度コンクリートの圧縮強度試験結果に及ぼ 寸影響について実験的および解析的に検証した。

\footnotetext{
* 東京工芸大学大学院工学研究科建築学専攻 (東京検査(侏) 代表取締役社長)

** 東京工芸大学工学部建築学科 教授 · 博士 (工学)

*** 大成建設(侏技術センター 主席研究員・博士 (工学)

**** 東京検査(株)建材研究所 所長

Graduate Student, Graduate School of Eng., Tokyo Polytechnic Univ. (President, Tokyo Kensa Co., Ltd.)

Prof., Dept. of Architecture, Faculty of Eng., Tokyo Polytechnic Univ., Dr. Eng.

Chief Research Engineer, Technology Center, Taisei Corp., Ph. D.

Director, Construction Materials Laboratory, Tokyo Kensa Co., Ltd.
} 


\section{2. 実験計画}

\section{1 要因と水準}

実験の要因と水準を表 1 に示す。コンクリートの調合は 5 種類と L, 圧縮強度 $180 \mathrm{~N} / \mathrm{mm}^{2}$ 程度の超高強度領域加圧縮強度 $20 \mathrm{~N} / \mathrm{mm}^{2}$ 程 度の一般的な強度領域までを網羅するように計画した。供試体の設 置位置としては，供試体の中心軸と加圧板の中心のズレ（以下，供 試体のズレと称す）として JIS A 1108 の許容範囲の下限と上限とな る $0 \mathrm{~mm}$ と $1 \mathrm{~mm}$ (直径 $100 \mathrm{~mm}$ の供試体で $1 \%$ ), および全体の傾向を把 握するための $3 \mathrm{~mm}, 6 \mathrm{~mm}, 9 \mathrm{~mm}$ の 5 種類を検討することとした。なお， 試験機の球座は一般的な試験機関の仕様を模擬し, 回転を固定でき ない球座に潤滑剤として鉱物油を使用したものとした。

\section{2 使用材料と調合}

実験に使用した材料の一覧を表 2 に, 各コンクリートの使用材料 の組み合わせを表 3 に示す。使用材料の選定と組み合わせは，実際 の建設工事で使用されているものを参考に決めている。

コンクリートの調合を表 4 に示す。水結合材比の範囲は 14\%〜 $70 \%$ である。いずれの調合も打込み後に 91 日を超えるような十分な 材齢をとることで実験に影響を及ぼさないような安定した強度が得 られるようにしている。ただし, 目標圧縮強度 $20 \mathrm{~N} / \mathrm{mm}^{2}$ のコンクリ 一トだけは，フレッシュコンクリートの性状などの観点から設定水 結合材比 $70 \%$ が上限であると考え，強度発現途中の材齢 14 日で試 験を行うことで，目標強度となるコンクリートを作ることとした。

\section{3 供試体の作製}

圧縮強度試験用の供試体は, 各目標圧縮強度の試験条件ごとに 3 本ずつ作製した。大量の供試体を同時に採取する必要があるため, 型枠にはJIS A 5308「レディーミクストコンクリート」附属書 E（規 定）軽量型枠に適合する軽量型枠を使用した。供試体の寸法は $\Phi 100$ $\times 200 \mathrm{~mm}$ とし, 載荷面の処理は両面研磨とした。整形した供試体に 関しては，載荷面の平面度，各寸法などが JIS A 1132「コンクリー 卜強度試験用供試体の作り方」の許容範囲に入っていることを確認 することとした。なお, 筆者らの既往の研究で得られた知見 ${ }^{1)}$ から， 供試体の平面度の測定は図 1 に示寸 17 点に関して行うこととした。

\section{4 圧縮強度試験とひずみの測定}

圧縮強度試験は，JIS A 1108 に準じて行うこととした。実験要因 となる供試体のズレは，JIS 適用範囲外となる $3 \mathrm{~mm}, 6 \mathrm{~mm}$ および $9 \mathrm{~mm}$ を含んでいる。なお，荷重速度は $0.6 \mathrm{~N} / \mathrm{mm}^{2} /$ 秒を目標值とした。

供試体のズレは，供試体の偏心荷重の基となることが予測できる

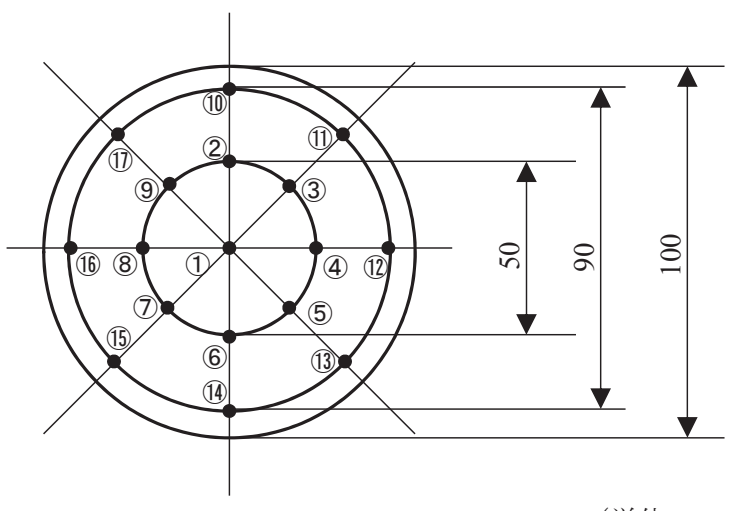

図 1 平面度の測定位置

(単位 : mm)
表 1 実験の要因と水準

\begin{tabular}{c|c|c}
\hline 要因 & 要因数 & 水準 \\
\hline \hline 目標圧縮強度 & 5 & $180,150,100,50,20 \mathrm{~N} / \mathrm{mm}^{2}$ \\
\hline 供試体のズレ & 5 & $0,1,3,6,9 \mathrm{~mm}$ \\
\hline
\end{tabular}

表 2 使用材料一覧

\begin{tabular}{|c|c|c|c|}
\hline 種類 & 記号 & 名称 & 備考 \\
\hline \multirow{3}{*}{ 結合材 } & B1 & 高強度用結合材 $1 *^{6}$ & 密度 $3.00 \mathrm{~g} / \mathrm{cm}^{3}$ \\
\hline & B2 & 高強度用結合材 $2 * *$ & 密度 $2.99 \mathrm{~g} / \mathrm{cm}^{3}$ \\
\hline & B3 & 普通ポルトランドセメン & 密度 $3.16 \mathrm{~g} / \mathrm{cm}^{3}$ \\
\hline \multirow{3}{*}{ 細骨材 } & S1 & 安山岩系砕砂 & 表乾密度 $2.62 \mathrm{~g} / \mathrm{cm}^{3}$ \\
\hline & $\mathrm{S} 2$ & 硬質砂岩系砕砂 & 表乾密度 $2.63 \mathrm{~g} / \mathrm{cm}^{3}$ \\
\hline & S3 & 天然砂 & 表乾密度 $2.63 \mathrm{~g} / \mathrm{cm}^{3}$ \\
\hline \multirow{2}{*}{ 粗骨材 } & G1 & 安山岩系砕石 & 表乾密度 $2.64 \mathrm{~g} / \mathrm{cm}^{3}$ \\
\hline & G2 & 安山岩系砕石 & 表乾密度 $2.63 \mathrm{~g} / \mathrm{cm}^{3}$ \\
\hline
\end{tabular}

* 中庸熱术 ルララドセメント+高強度用混和材 + 膨張材 $=729+312+30$

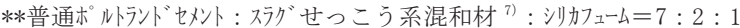

表 3 使用材料の組み合わせ

\begin{tabular}{c|c|c|c}
\hline $\begin{array}{c}\text { 目標圧縮強度 } \\
\left(\mathrm{N} / \mathrm{mm}^{2}\right)\end{array}$ & 結合材 & 細骨材 & 粗骨材 \\
\hline \hline 180 & $\mathrm{~B} 1$ & $\mathrm{~S} 1$ & $\mathrm{G} 1$ \\
\hline 150 & $\mathrm{~B} 2$ & $\mathrm{~S} 2$ & $\mathrm{G} 2$ \\
\hline 100 & $\mathrm{~B} 3$ & $\mathrm{~S} 2: \mathrm{S} 3=8: 2$ & $\mathrm{G} 2$ \\
\hline 50 & $\mathrm{~B} 3$ & $\mathrm{~S} 2: \mathrm{S} 3=8: 2$ & $\mathrm{G} 2$ \\
\hline 20 & $\mathrm{~B} 3$ & $\mathrm{~S} 2: \mathrm{S} 3=8: 2$ & $\mathrm{G} 2$ \\
\hline
\end{tabular}

表 4 コンクリートの調合

\begin{tabular}{c|c|c|c|c|c}
\hline \multirow{2}{*}{$\begin{array}{c}\text { 目標圧縮強度 } \\
\left(\mathrm{N} / \mathrm{mm}^{2}\right)\end{array}$} & \multicolumn{5}{|c}{ 単位量 $\left(\mathrm{kg} / \mathrm{m}^{3}\right)$} \\
\cline { 2 - 6 } & W/B (\%) & 結合材 & 水 & 細骨材 & 粗骨材 \\
\hline \hline 180 & 14 & 1071 & 150 & 616 & 620 \\
\hline 150 & 20 & 800 & 160 & 672 & 807 \\
\hline 100 & 40 & 425 & 170 & 907 & 869 \\
\hline 50 & 60 & 300 & 180 & 857 & 931 \\
\hline 20 & 70 & 264 & 185 & 844 & 962 \\
\hline
\end{tabular}

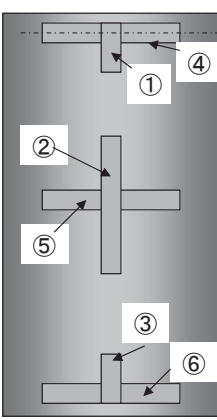

水平 $60 \mathrm{~mm}$ ゲージの 芯まで $7 \mathrm{~mm}$

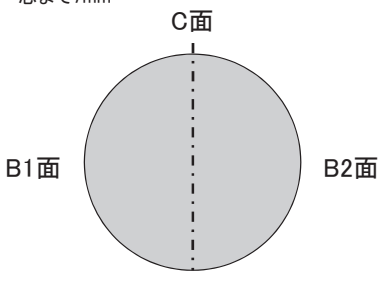

A面

変動要因にあわせ, 供試体の中心を こちらに $1,3,6,9 \mathrm{~mm}$ ズラして試験を行う。

図 2 ひずみ測定位置 
ため, 供試体には複数のワイヤー・ストレイン・ゲージ (以下, W. S. G. と称す）を貼付し，供試体全体のひずみを測定することとした。供 試体のひずみ測定位置を図 2 に示す。供試体の縦ひずみは, 図中に 示す A, B1, B2, C の 4 側面の上端部と下端部の近傍および中央部で測 定した。横ひずみは, A, B1，Cの 3 側面で測定した。使用したW. S. G.

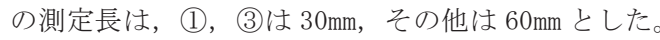

供試体の設置位置は, 測定位置 A と C をつなぐ直線上をズラして いくものとし，供試体をズラ寸場合は，測定位置 Aを中心から遠く に，測定位置 Cを中心に近づくように，供試体を設置した。

\section{3. 実験結果}

\section{1 供試体の整形状態の確認}

供試体の整形状態を確認した一例として, 供試体の載荷面の平面 度を確認した結果を図 3 に示す。今回の実験に使用する供試体の端 面は, すべて JIS A 1132 の許容範囲に入っていた。また, 整形状 態の確認では，隣接する面の角度が JIS A 1132 の許容範囲である $90 \pm 0.5^{\circ}$ の範囲に入っていることなども確認した。これの供試体 の整形状態に関する前提はいずれも誤差 0 とはならないが，筆者ら の既往の研究で得られた知見 ${ }^{11}$ などを踏まえ，本研究では無視でき る範囲に整形できていると考えることとした。

\section{2 圧縮強度}

圧縮強度試験結果の一覧を表 5 に示す。供試体のズレが $0 \mathrm{~mm}$ であ る場合の試験結果から, 各コンクリートは概数目標の圧縮強度とな ったことがわかる。また, 供試体が偏心圧縮となることから, 圧縮 強度試験結果のばらつきが極端に大きくなることも懸念したが, 試 験の妥当性を疑うほどのばらつきにはならなかった。

各コンクリートについて, 設置位置と圧縮強度の関係を整理した ものを図 4 に示す。今回の実験範囲では, JIS A 1108 で許容される $1 \mathrm{~mm}$ という供試体のズレであれば，供試体を中心に置いた場合と遜 色ない結果が得られることがわかった。ただし，供試体のズレが大 きくなると，顕著に圧縮強度が低下寸る結果も得られた。

次に，供試体のズレによる強度低下が，コンクリートの圧縮強度 が異なっても同じように生じているのかを調べるため, 図 4 の縦軸 を, 供試体のズレを 0 とした場合の圧縮強度に対する強度比で作図 し直した。結果を図 5 に示す。図 5 より, 供試体のズレは, 圧縮強 度 $20 \mathrm{~N} / \mathrm{mm}^{2}$ や $50 \mathrm{~N} / \mathrm{mm}^{2}$ の比較的低い強度のコンクリートよりも, 圧縮

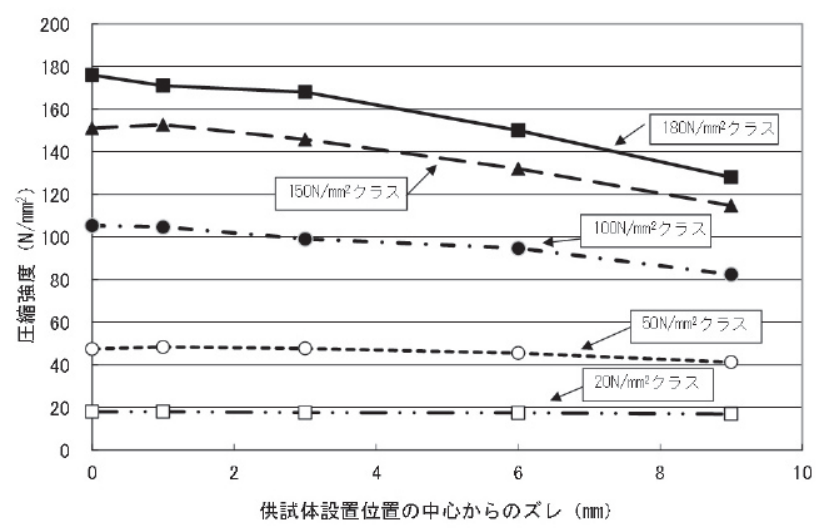

図 4 供試体のズレと圧縮強度の関係

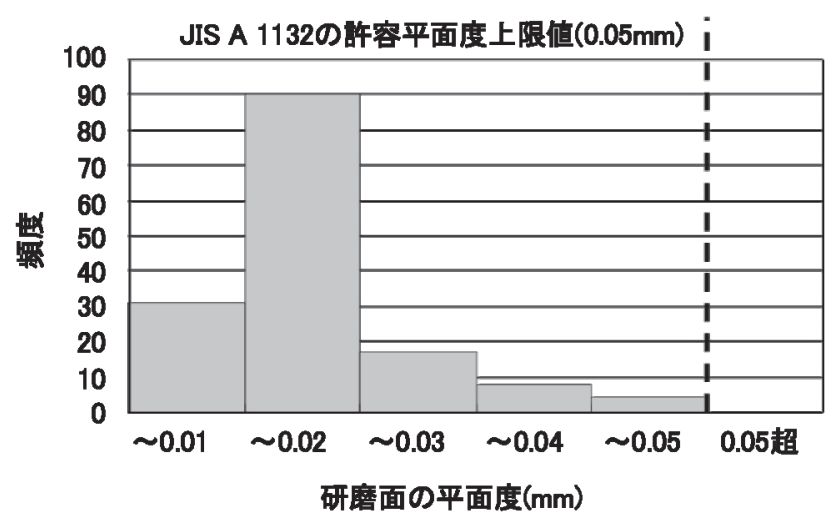

図 3 供試体の載荷面の平面度測定結果

表 5 圧縮強度試験結果

\begin{tabular}{|c|c|c|c|c|c|c|c|c|}
\hline \multirow{2}{*}{ 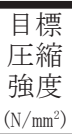 } & \multirow{2}{*}{$\begin{array}{l}\text { 供試 } \\
\text { 体の } \\
\text { ズレ } \\
(\mathrm{mm})\end{array}$} & \multicolumn{4}{|c|}{ 圧縮強度 $\left(\mathrm{N} / \mathrm{mm}^{2}\right)$} & \multirow{2}{*}{$\begin{array}{c}\text { 標隻 } \\
\text { 偏差 } \\
\left(\mathrm{N} / \mathrm{mm}^{2}\right)\end{array}$} & \multirow{2}{*}{$\begin{array}{c}\text { 変動 } \\
\text { 係数 } \\
(\%)\end{array}$} & \multirow{2}{*}{$\begin{array}{l}\text { 圧縮 } \text { 強度 } \\
\text { 比* }\end{array}$} \\
\hline & & 1 & 2 & 3 & 平均 & & & \\
\hline \multirow{5}{*}{180} & 0 & 177 & 180 & 172 & 176 & 3. 3 & 1.9 & 100 \\
\hline & 1 & 168 & 172 & 173 & 171 & 2.2 & 1.3 & 97 \\
\hline & 3 & 165 & 167 & 171 & 168 & 2.5 & 1.5 & 96 \\
\hline & 6 & 151 & 152 & 147 & 150 & 2.2 & 1.4 & 85 \\
\hline & 9 & 134 & 130 & 120 & 128 & 5.9 & 4.6 & 73 \\
\hline \multirow{5}{*}{150} & 0 & 153 & 148 & 152 & 151 & 2.2 & 1.4 & 100 \\
\hline & 1 & 158 & 149 & 151 & 153 & 3.9 & 2.5 & 101 \\
\hline & 3 & 136 & 154 & 147 & 146 & 7.4 & 5.1 & 97 \\
\hline & 6 & 137 & 131 & 128 & 132 & 3.7 & 2.8 & 87 \\
\hline & 9 & 115 & 113 & 116 & 115 & 1.2 & 1.1 & 76 \\
\hline \multirow{5}{*}{100} & 0 & 106 & 105 & 105 & 105 & 0.5 & 0.4 & 100 \\
\hline & 1 & 105 & 105 & 104 & 105 & 0.5 & 0.5 & 100 \\
\hline & 3 & 98.7 & 97.4 & 101 & 99.0 & 1.5 & 1.5 & 94 \\
\hline & 6 & 94.5 & 96.1 & 93.5 & 94.7 & 1.1 & 1.1 & 90 \\
\hline & 9 & 83.0 & 80.3 & 83.8 & 82.4 & 1.5 & 1.8 & 78 \\
\hline \multirow{5}{*}{50} & 0 & 47.6 & 47.8 & 46.8 & 47.4 & 0.4 & 0.9 & 100 \\
\hline & 1 & 47.1 & 49.4 & 48.5 & 48.3 & 0.9 & 2.0 & 102 \\
\hline & 3 & 46.4 & 49.2 & 47.4 & 47.7 & 1.2 & 2.4 & 101 \\
\hline & 6 & 45.9 & 44.1 & 46.5 & 45.5 & 1.0 & 2.2 & 96 \\
\hline & 9 & 40.8 & 42.1 & 40.8 & 41.2 & 0.6 & 1.5 & 87 \\
\hline \multirow{5}{*}{20} & 0 & 18.1 & 17.7 & 18.0 & 17.9 & 0.2 & 0.9 & 100 \\
\hline & 1 & 18.2 & 18.0 & 17.8 & 18.0 & 0.2 & 0.9 & 101 \\
\hline & 3 & 17.8 & 17.3 & 17.4 & 17.5 & 0.2 & 1.2 & 98 \\
\hline & 6 & 17.3 & 17.7 & 17.2 & 17.4 & 0.2 & 1.2 & 97 \\
\hline & 9 & 16.7 & 17.2 & 16.9 & 16.9 & 0.2 & 1.2 & 94 \\
\hline
\end{tabular}

*供試体のズレが 0 である場合を 100 とした場合の圧縮強度比

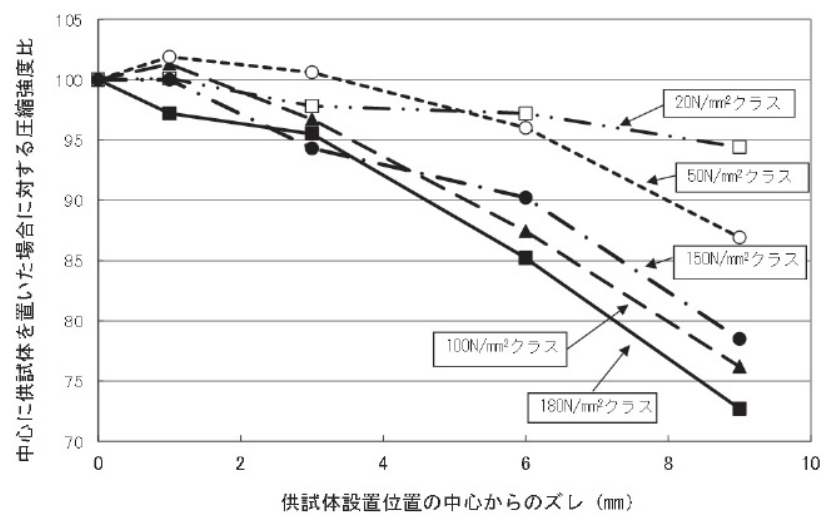

図 5 供試体のズレと圧縮強度比の関係 
強度 $100 \mathrm{~N} / \mathrm{mm}^{2}$ 以上の超高強度コンクリートで顕著な影響となるこ とがわかる。具体的な值で示すと, 最も圧縮強度の高い $180 \mathrm{~N} / \mathrm{mm}^{2}$ ク ラスでは, 供試体のズレが $6 \mathrm{~mm}$ になると約 15\%の強度低下, $9 \mathrm{~mm}$ にな ると $30 \%$ 近い強度低下が見られたのに対し, $20 \mathrm{~N} / \mathrm{mm}^{2}$ クラスでは, $6 \mathrm{~mm}$ で約 3\%の強度低下, $9 \mathrm{~mm}$ で約 $6 \%$ の強度低下に留まっている。これら の知見を整理すると, 供試体の設置位置は JIS A 1108 の範囲内 $(1 \mathrm{~mm}$ 以内のズレ) であれば問題は生じないと考えられるものの, 何かの 間違いでそれを超えるようなズレが生じれば圧縮強度を過小評価す ることとなる。その影響は特に高強度領域では大きいと考えられた。

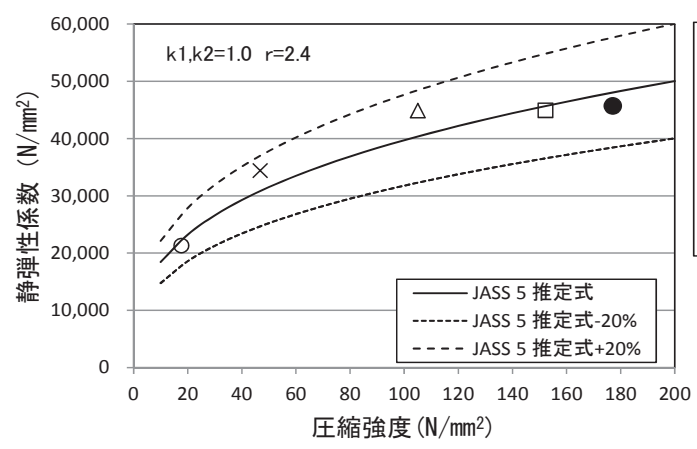

図 6 圧縮強度と静弾性係数の関係
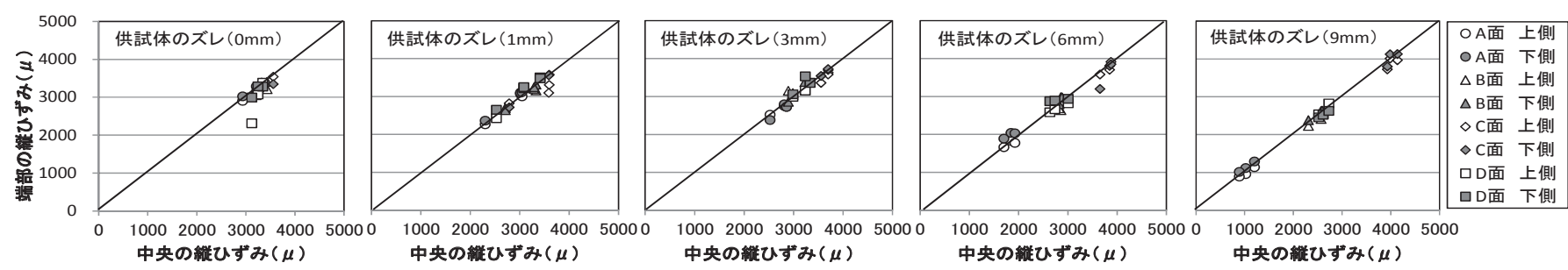

中央の縦ひずみ $(\mu)$

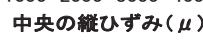

0002000300040005000

(目標圧縮強度 $180 \mathrm{~N} / \mathrm{mm}^{2}$ )
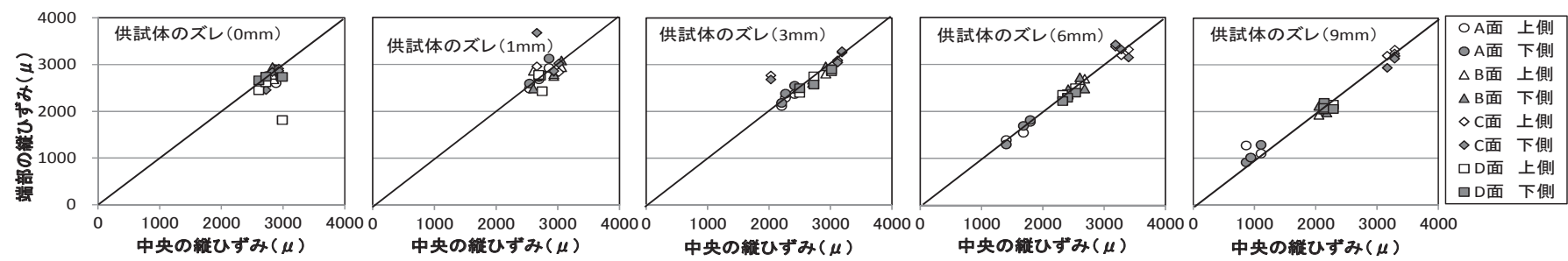

中央の縦ひずみ $(\mu)$

中央の縦ひずみ $(\mu)$

中央の縦ひずみ $(\mu)$
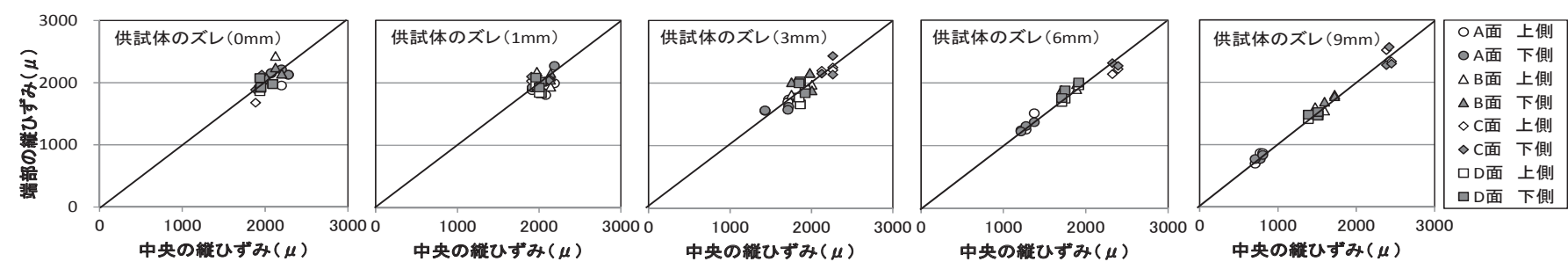

(目標圧縮強度 $100 \mathrm{~N} / \mathrm{mm}^{2}$ )
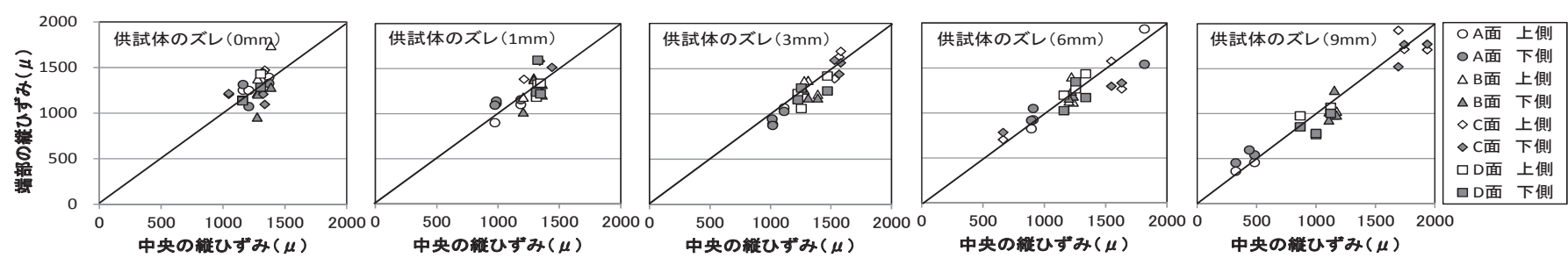

(目標圧縮強度 $50 \mathrm{~N} / \mathrm{mm}^{2}$ )
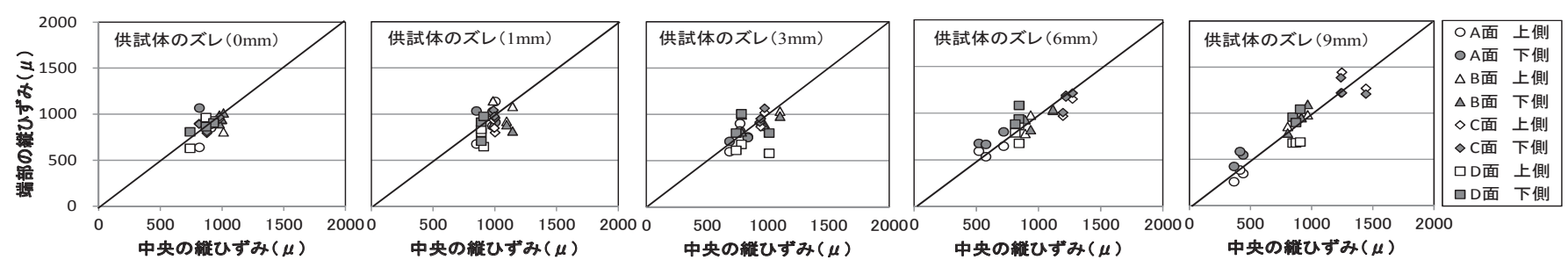

$\left(\right.$ 目標圧縮強度 $\left.20 \mathrm{~N} / \mathrm{mm}^{2}\right)$

図 7 最大荷重の $80 \%$ の時の中央の縦ひずみと端部の縦ひずみの関係 

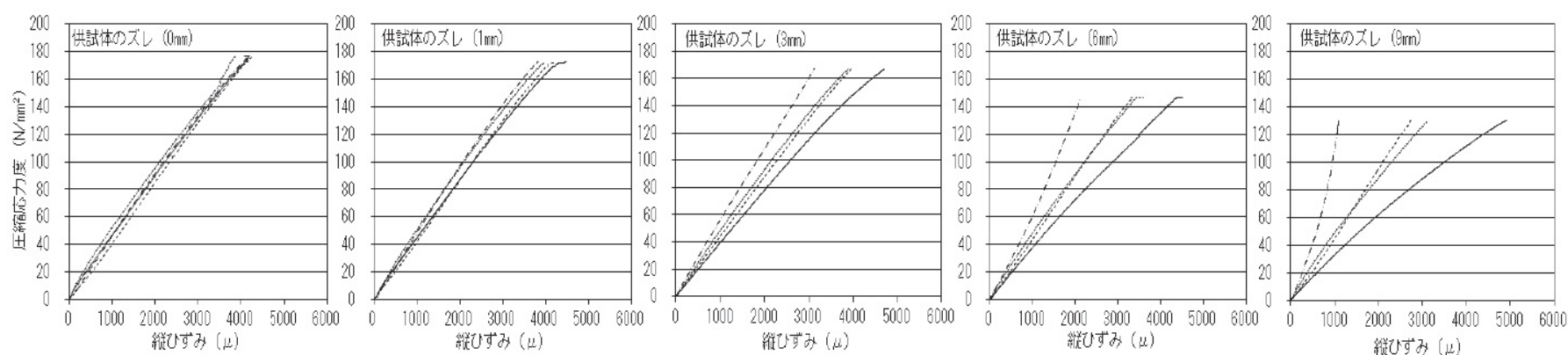

（目標圧縮強度 $180 \mathrm{~N} / \mathrm{mm}^{2}$ )
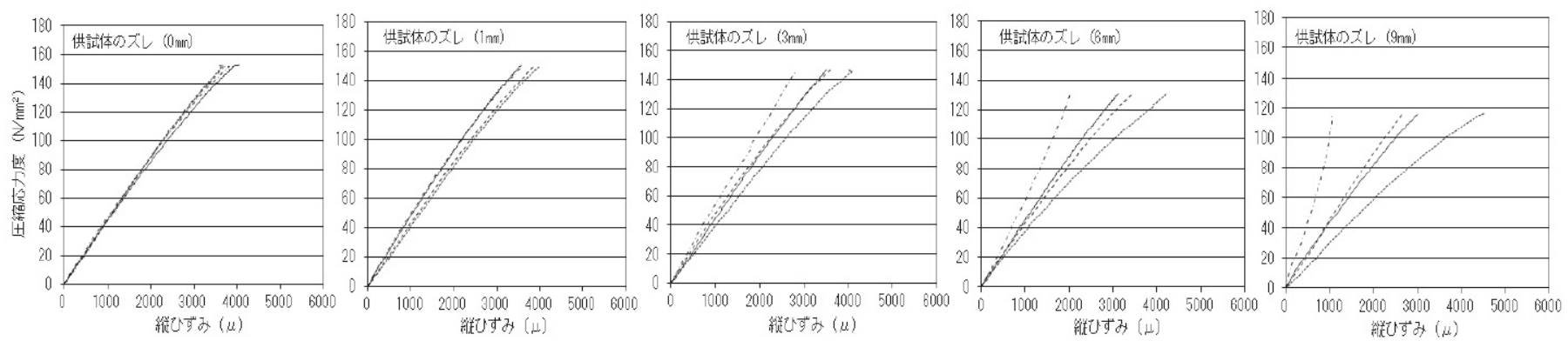

（目標圧縮強度 $150 \mathrm{~N} / \mathrm{mm}^{2}$ )
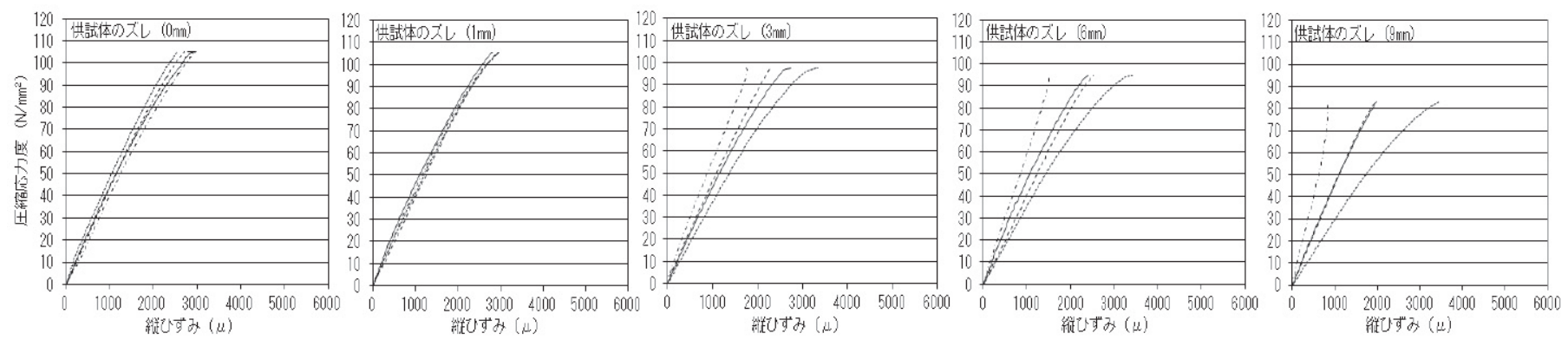

（目標圧縮強度 $100 \mathrm{~N} / \mathrm{mm}^{2}$ )
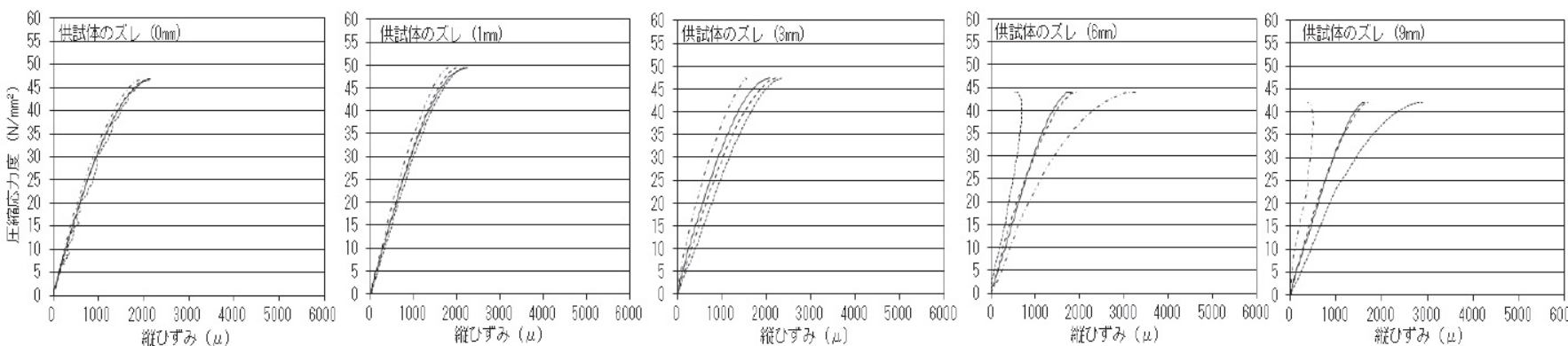

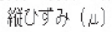

絿しすす孙 $(\mu)$

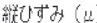

(目標圧縮強度 $50 \mathrm{~N} / \mathrm{mm}^{2}$ )
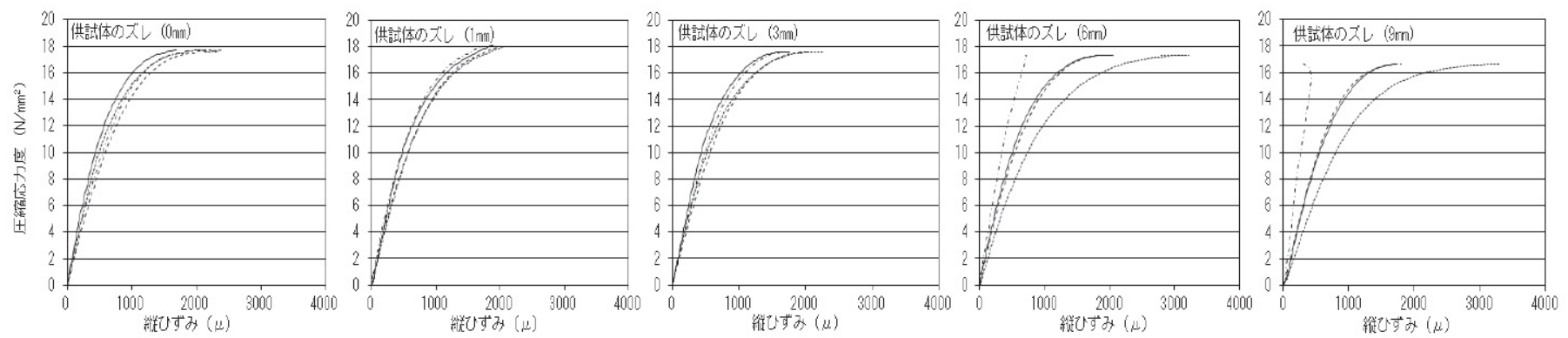

（目標圧縮強度 $20 \mathrm{~N} / \mathrm{mm}^{2}$ )

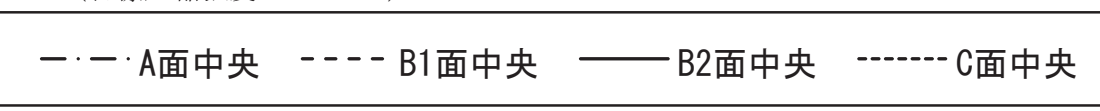

図８圧縮応力度と縦ひずみの関係 


\section{3 変形性状}

3.2 の検討では, 圧縮強度試験結果について整理した。この整理 によって, 供試体のズレの影響で圧縮強度試験結果が低くなるとい う大まかな傾向を示すことができたが，なぜそのような傾向が生じ るのかは推論の域を脱しない。そこで, ここでは供試体に添付した W. S. G.のひずみを分析し，供試体のズレが供試体のひずみにどのよ うな影響を与えたのかを検討することとした。なお, 偏心荷重が加 わると供試体は微妙に傾斜することになるが，ここで扱うひずみに

は，この微妙な傾斜による補正などは行っていない。

\section{3. 1 縦ひずみ}

供試体の縦ひずみは，A，B1，B2，Cの 4 側面の上端部と下端部の近 傍および中央部で測定した。上端部と下端部の近傍の縦ひずみを測 定した理由は, 供試体に偏心荷重が作用した場合に, 端部近傍のみ の縦ひずみが進行するような破壊が生じていないことを確認するた めである。データの整理に先立ち, 供試体のズレが 0 の場合の中央 部の縦ひずみ測定結果を用いて各コンクリートの静弾性係数を求め た結果を図 6 に示す。図 6 に示すように, 今回の実験に用いたコン クリートの静弹性係数は, 日本建築学会建築工事標準仕様書 ・ 同解 説 JASS5 鉄筋コンクリート工事に示される推定式 ${ }^{8)}$ で概ね推定でき る範囲のものであった。

中央部と端部近傍の縦ひずみを比較した結果を図 7 に示す。図 7 には, すべての供試体に関して, 最大応力の $80 \%$ の時の中央部の縦 ひずみと端部近傍の縦ひずみの関係をプロットした。ただし, 明ら かに W. S. G. が剥がれるような不備が起こったと読み取れる一部の データは計測不備と考え, 作図から除外している。図 7 からわかる ように, 若干のデータのばらつきはあるものの, 変動要因に関わら ず，中央部の縦ひずみと端部近傍の縦ひずみは概ね同様の值となっ ている。したがって, 供試体に偏心載荷が生じたとしても, 供試体 全体の縦ひずみは概ね均等になっているものと考えられた。実際に は供試体中央部は端部よりも横ひずみが大きくなるため, 縦ひずみ が完全に均等になると言いきれる訳ではないが, 本論では, 供試体 の縦方向のひずみは高さ方向で均等であると仮定して検討を進める こととする。

各目標圧縮強度の試験条件ごとに, 供試体の応力度と縦ひずみの 関係を整理したものを図 8 に示す。図 8 に用いたデータは, 各目標 圧縮強度の試験条件ごとに, 代表的な供試体のものを示している。 代表的な供試体は各条件の平均圧縮強度に近いものを基本としてい るが，測定された縦ひずみのデータが明らかにW.S. G. が剥がれるよ うな不備が起こったと読み取れるものである場合には, 他の供試体 で代用している。図8からわかるように，供試体のズレが大きくな るほど加圧板の中心から離れることとなる A 側面のひずみは減少し, 加圧板の中心に近づくこととなる C 側面のひずみは増大した。

次に，供試体の縦ひずみが平面的にどのような分布となっている のかを検討するため, $\mathrm{A}, \mathrm{C}$ 面の平均縦ひずみと B1, B2 面の平均縦ひ ずみの関係を整理した。最大荷重の $95 \%$ の状態を整理した結果を図 9 に示す。前述した図 8 の整理で, 加圧板の中心から離れることと なる A 側面のひずみが減少し, 加圧板の中心に近づくこととなる C 側面のひずみが増大寸ることが把握できたが，図 9 からは，A，C 面 の平均縦ひずみと $\mathrm{B} 1, \mathrm{~B} 2$ 面の平均縦ひずみが概ね同じであることが 確認できる。加圧版の剛性を考えれば当然のことであるが，供試体
のズレによる偏心載荷は，平面的に供試体の一部に大きな力を与え ている訳ではなく, 図 10 の左図のように加圧板と球座面の平面度 を維持しながら斜めに載荷していることを確認したことになる。な お，実際には供試体の軸全体が偏心によってわずかに湾曲している と考えられるが，本論で扱っている偏心距離は比較的小さいことか ら，図10のイメージでは考慮していない。

こまでの結果を踏まえると，供試体の平面内の縦ひずみの分布は 図 10 の右図のように仮定することができる。そこで図 10 右図の仮 定と最大荷重の $95 \%$ の時の縦ひずみ実測值から, 実験時の圧縮応力 度を推測できるのかを試みた。ここでの推定では，A 面および C 面 の縦ひずみ実測值から，図 10 右図に示す中間微小区間の縦ひずみを 直線補間によって求め, それぞれの微小区間の縦ひずみから求めた 応力度を合算して圧縮強度を推定した。なおここでの応力度とひ ずみの関係は, 静弾性係数ではなく, 供試体のズレを 0 とした供試 体のデータを基に, 以下に示寸武藤式 ${ }^{9)}$ と六車・渡辺式 ${ }^{10)}$ によっ て作成したプレーンコンクリートの応力度と縦ひずみ曲線で与えて いる。

武藤式，六車・渡辺式と今回の実験結果の整合性を図 11 に示す。 ここでの実測值は, 各強度クラスのコンクリートの供試体のズレを 0 とした場合の代表的な供試体の值を示している。図 11 からわかる ように, $20 \mathrm{~N} / \mathrm{mm}^{2}$ クラスのコンクリートは武藤式, $50 \sim 180 \mathrm{~N} / \mathrm{mm}^{2}$ クラ スのコンクリートは六車・渡辺式で概称モデル化することが可能で あった。いずれの式も今回使用したコンクリートの圧縮強度や最大 応力時のひずみなどをデータとして入力しているため, コンクリー トの強度・変形性状をほぼ再現できている。ただし，今回の実験で

○武藤式

$$
\begin{aligned}
& { }_{c} \sigma={ }_{c} \sigma_{B} \times{ }_{c} \eta \\
& { }_{c} \eta=6.75 \times\left(\mathrm{e}^{-0.812 \xi}-e^{-1.218 \xi}\right) \\
& \xi=\frac{c^{\varepsilon}}{{ }^{\varepsilon} \varepsilon_{B}} \\
& \text { ○六車・渡辺式 }
\end{aligned}
$$

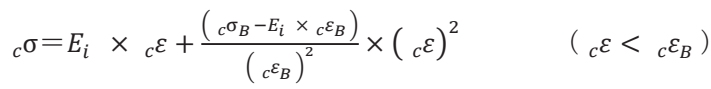

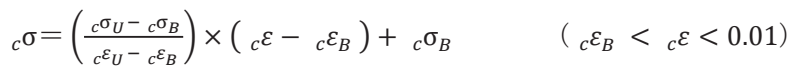

$$
\begin{aligned}
& { }_{c} \sigma_{U}=\frac{2 \times\left(s-{ }_{c} \sigma_{B} \times{ }_{c} \varepsilon_{B}\right)}{{ }^{\varepsilon_{U}}+{ }_{c^{\varepsilon_{B}}}}+{ }_{{ } \varepsilon_{B}} \\
& \text { ここに, }{ }_{c} \sigma \quad \text { : コンクリートの応力度 }\left(\mathrm{N} / \mathrm{mm}^{2}\right) \\
& { }_{c} \sigma_{B} \quad: \text { コンクリートの圧縮強度 }\left(\mathrm{N} / \mathrm{mm}^{2}\right) \\
& { }_{c} \sigma_{u} \quad \text { : コンクリートの圧縮限界時の圧縮強度 }\left(\mathrm{N} / \mathrm{mm}^{2}\right) \\
& { }_{c} \varepsilon \quad: \text { コンクリートの縦ひずみ } \\
& { }_{c} \varepsilon_{B} \quad: \text { コンクリートの最大応力時のひずみ } \\
& { }_{c} \varepsilon_{U} \quad: \text { コンクリートの圧縮限界時のひずみ } \\
& \left({ }_{c} \varepsilon_{U}=1.314{ }_{c} \varepsilon_{B}\right) \\
& { }_{c} \eta \quad \text { : 武藤式で使用する応力度算出用の変数 } \\
& \text { そ：武藤式で使用するひずみ算出用の変数 } \\
& E_{i} \quad \text { : コンクリートの静弾性係数 }\left(\mathrm{N} / \mathrm{mm}^{2}\right) \\
& S \text { : ピーク荷重までのプレーンコンクリートの応力 } \\
& \text { ひずみ曲線が囲む面積 }
\end{aligned}
$$




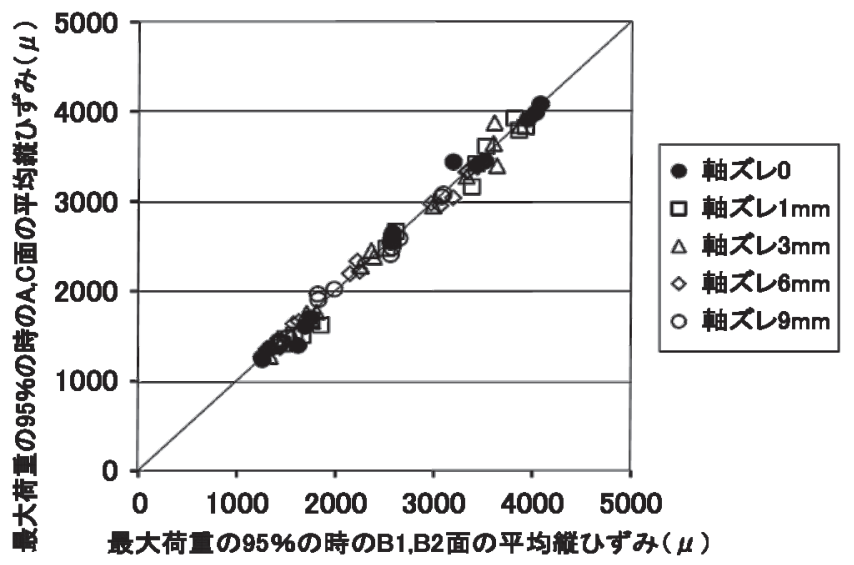

図 9 最大荷重の $95 \%$ の時の A, C 面と B1, B2 面の

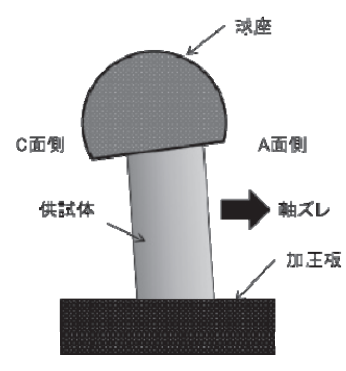

(偏心状態のイメージ $)$

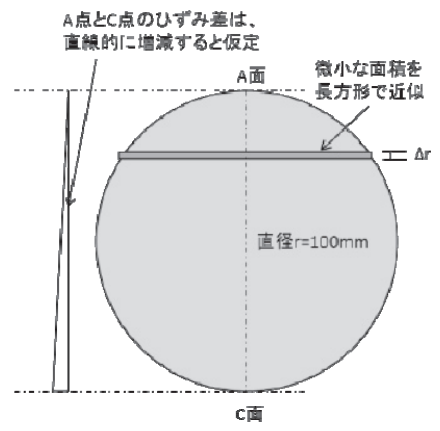

（平面内の縦ひずみ分布の仮定）

図 10 偏心状態のイメージと平面のひずみ分布の仮定

平均縦ひずみの関係
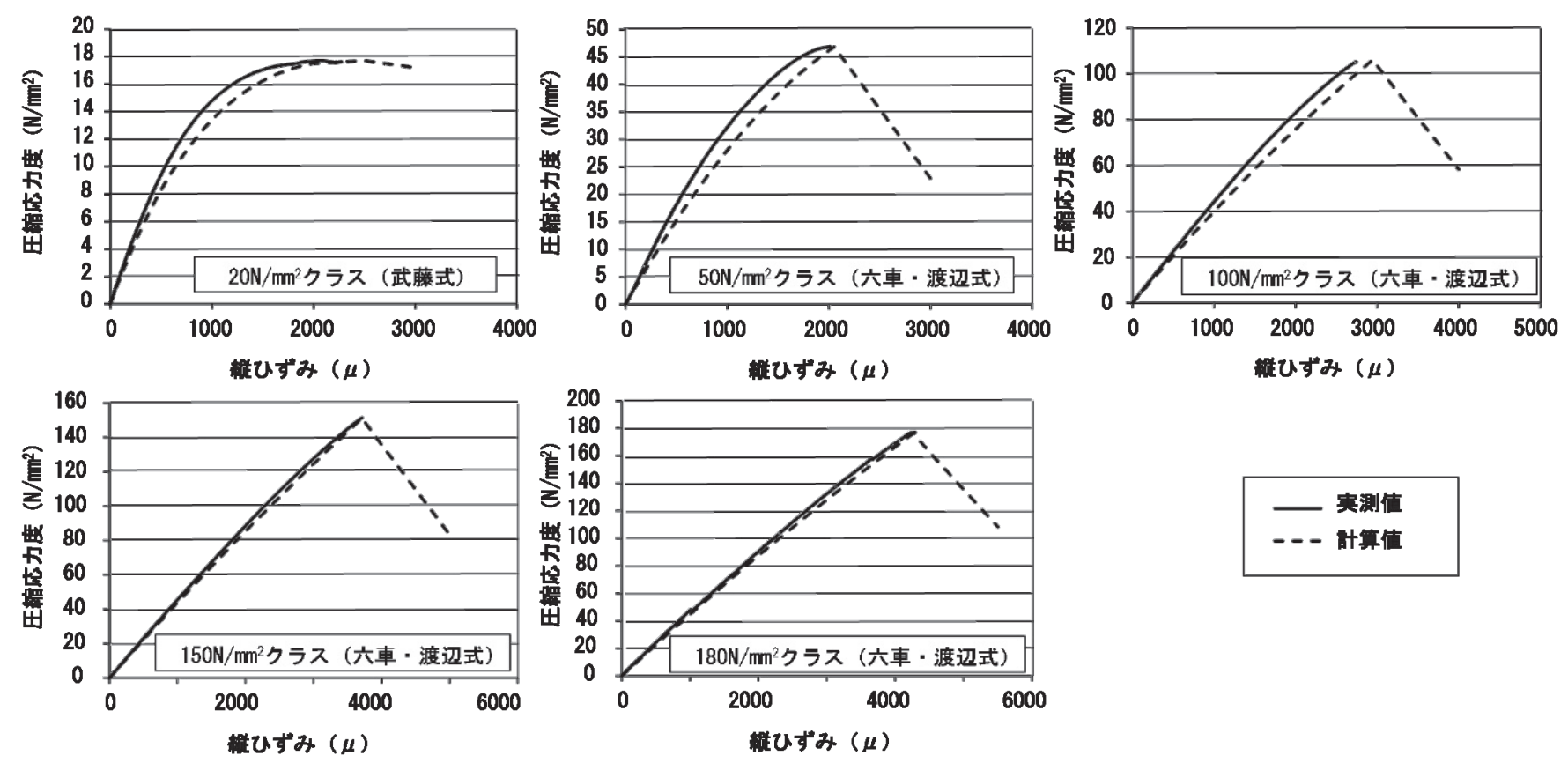

図 11 武藤式，六車・渡辺式によるコンクリートの応力度一縦ひずみ曲線の計算值と実測值の関係

は得られない最大応力度以降の下降勾配は, 各式の考え方をそのま ま適用している。

推定結果と実測值を比較した結果を図 12 に示す。図 12 からわか るように, 推定值は実測值と概社近い值となった。したがって, 縦 ひずみの実測值から，供試体のズレによっていずれの強度領域のコ ンクリートも圧縮強度試験結果が低くなるという現象や, その傾向 が高強度領域になるほど顕著になることが説明できたことになる。 また, 武藤式および六車・渡辺式によって仮定した図 11 の応力度と 縦ひずみの関係も概初妥当であると考えられた。そこで, 図 12 作成 時に求めた $\mathrm{A}$ 面と $\mathrm{C}$ 面の間の縦ひずみ分布をもとに, 武藤式, 六車・ 渡辺式から最大荷重の $95 \%$ の時の応力度の分布を計算した結果を

図 13 に示寸。図 13 からわかるように, 強度レベルの異なるコンク リートでは，供試体のズレによってもたらされる荷重の分布が異な

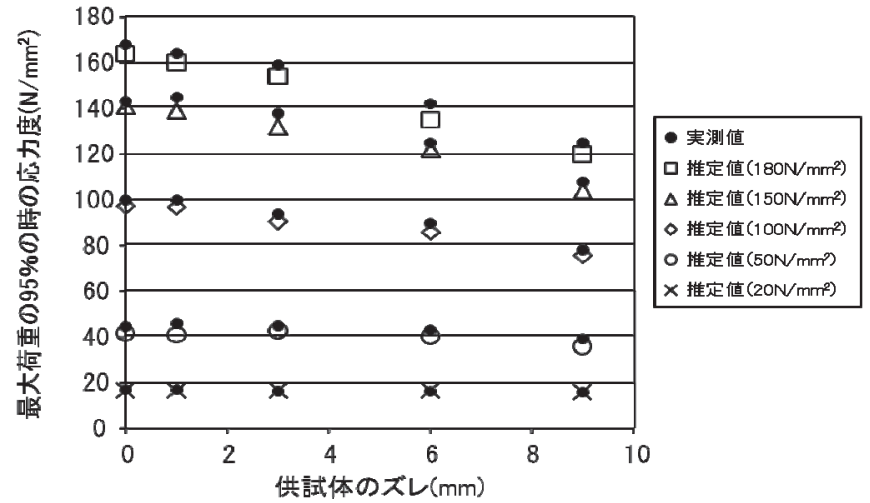

図 12 最大荷重の $95 \%$ の時の縦ひずみから算出した 推定圧縮応力度と実測值の関係 

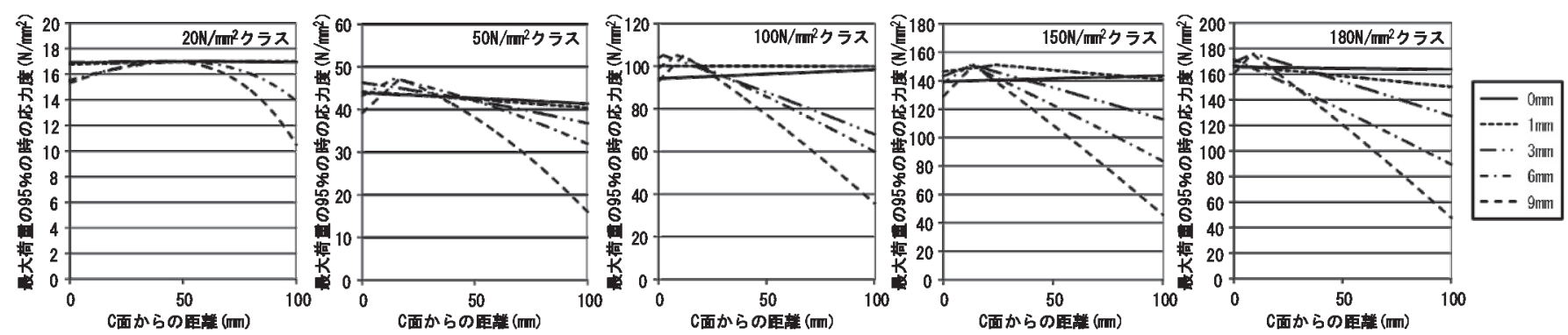

図 13 最大荷重の $95 \%$ の時の縦ひずみ分布から算出した A 面と C 面の間の応力分布

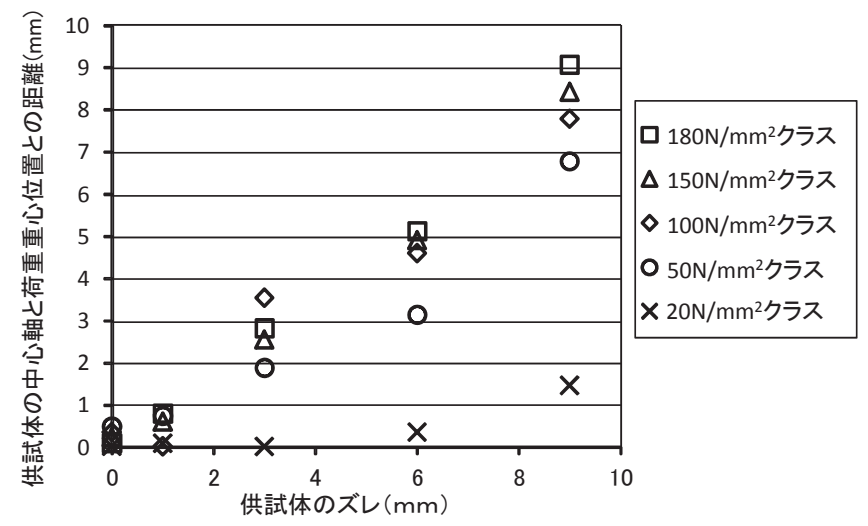

図 14 供試体のズレと荷重重心位置の関係

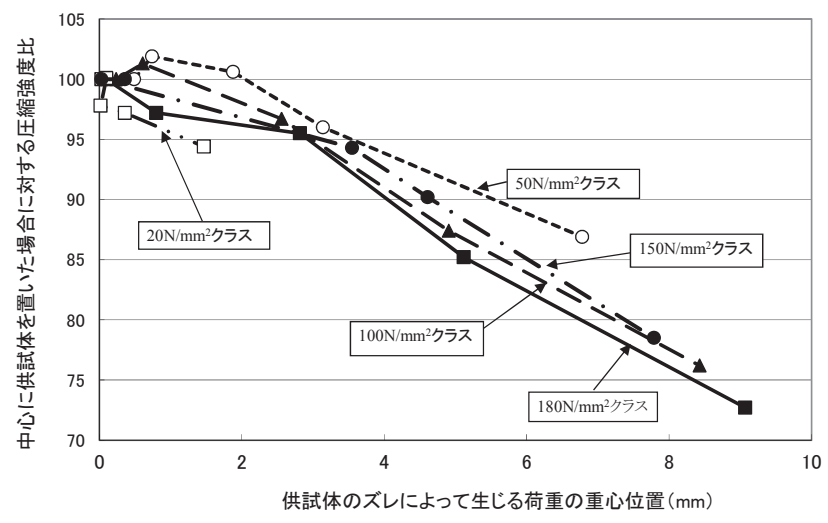

図 15 荷重重心位置と圧縮強度比の関係
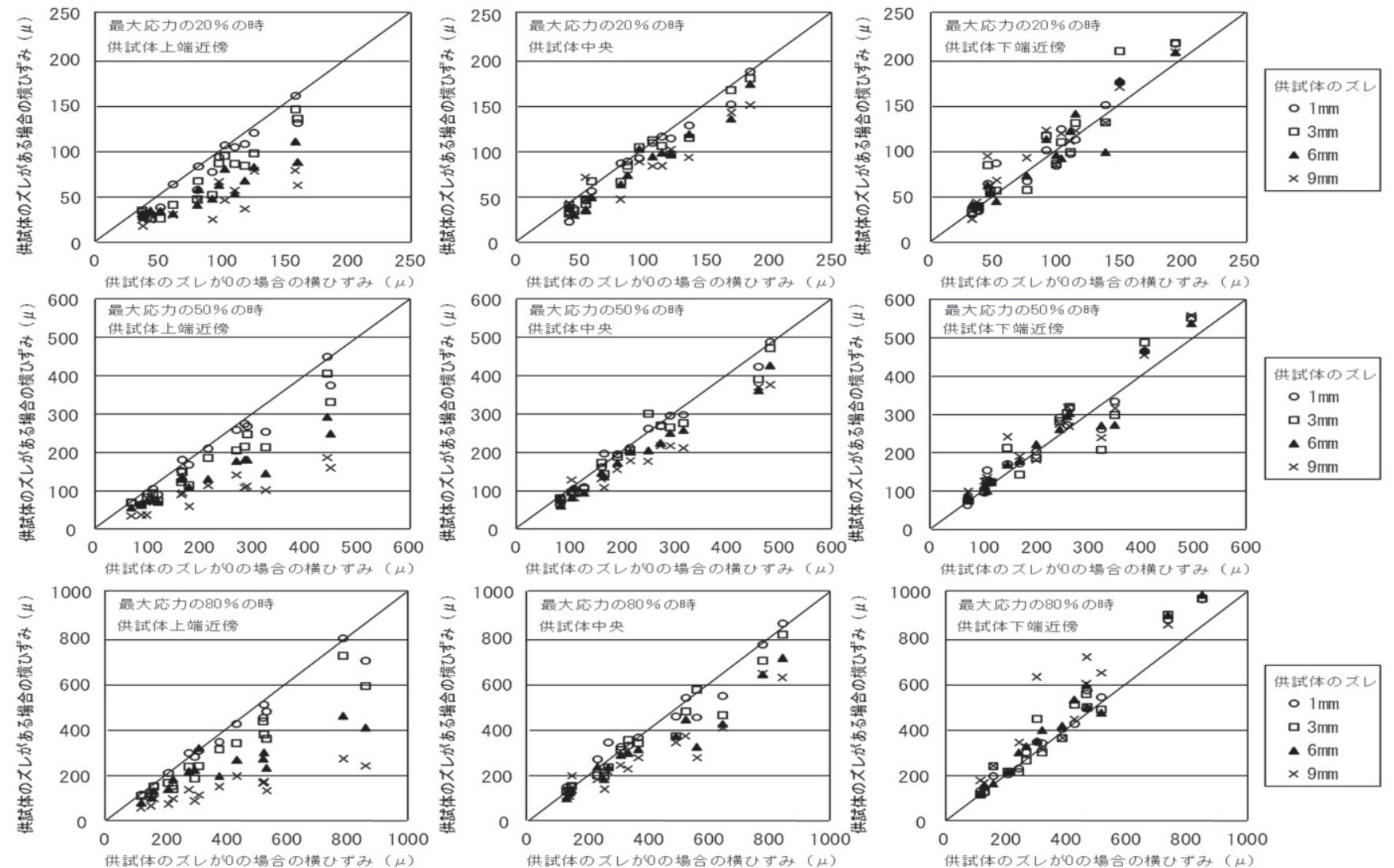

図 16 供試体のズレが横ひずみに与える影響 
る。これはコンクリートが高強度化するほど応力度とひずみの関係 が, より直線的になることに起因している。このような知見から, 図 13 の応力度分布と図 10 で示した微小領域の面積を用いて分布荷重 の重心位置を求めた結果を図 14 に示す。図 14 からわかるように, 見かけ上，供試体を同じ距離だけズラしたとしても，供試体の中心 軸と荷重の重心位置の差は, 強度レベルが高くなるほど大きくなる。 この結果を踏まえ, 今回の実験結果について, 荷重の重心位置と圧 縮強度比の関係をプロットすると図 15 ができる。図 15 からわかる ように, 荷重の重心位置で説明すると, 強度レベルに関わらず, 偏 心荷重による強度低下を概䄈表現できている。したがって, コンク リートの強度レベルが増大寸るほど, 供試体がズレることによって 受ける偏心荷重の影響が大きくなる理由の一つは, 供試体に作用す る荷重の重心位置に起因するものと考えられた。

\section{3.2 横ひずみ}

供試体の横ひずみは, A, B1, C の 3 側面の上端部と下端部の近傍お よび中央部で測定した。図 16 に供試体のズレが横ひずみに与える影 響を検討した結果を示す。図 16 は, 最大応力の $20 \%, 50 \%$ おび $80 \%$ の時の, 供試体のズレが 0 の場合の横ひずみと各設置位置の供 試体の横ひずみを比較したものである。プロット 1 点は， 3 本の供 試体の平均横ひずみ実測值を示している。また, 横ひずみは供試体 の上端部近傍, 下端部近傍および中央部の絶対值が異なることが周 知の事実であるので，作図はそれぞれについて行っている。なお， 煩雑となるのでコンクリートの圧縮強度レベルによってプロットを 区別していないが, 縦軸・横軸ともに, 横ひずみが大きくなるほど 高い強度のコンクリートのプロットとなる傾向にある。

図 16 からわかるように, 中央部, 下端部近傍に比心゙，上端部近傍 は供試体のズレが大きくなるほど横ひずみが小さくなることが確認 できた。この結果は, 供試体がズレることにより, 球座と接する供 試体上端部の設置圧による拘束力が上がることを示唆している。今 回の実験結果では, 横ひずみで生じている現象が圧縮強度試験結果 にどのような影響を与えるのかまでは確認できなかったが，少なく とも偏心荷重が供試体の縦方向の変形だけでなく, 横方向の変形に も影響するような作用を及ぼしていることまでは確認できた。この 点については今後の課題である。

\section{4.まとめ}

昨今用いられている圧縮強度 $20 \mathrm{~N} / \mathrm{mm}^{2}$ 程度の普通強度領域のコン クリートから $180 \mathrm{~N} / \mathrm{mm}^{2}$ 程度の超高強度領域までのコンクリートに 関し, 供試体の設置位置の誤差などに起因寸る比較的小さな偏心が 超高強度コンクリートの圧縮強度試験結果に及ぼす影響について実 験的および解析的に検証した。以下に, 結論を示す。

（1）JIS の許容範囲を超えて大きく供試体をズラした実験を行った 結果, いずれの強度領域のコンクリートでも供試体のズレが大 きくなるほど圧縮強度試験結果が低くなることが確認できた。
また，この結果を圧縮強度比で考えた場合，低強度領域よりも 超高強度領域のコンクリートで圧縮強度比が顕著に低下寸るこ とが確認できた。

（2）（1）の実験結果は，縦ひずみの実測值をもとに算出した圧縮強 度推定でも再現することが可能であった。この推定による供試 体の応力度分布から荷重の重心位置を求めると，見かけ上，供 試体を同じ距離だけズラしたとしても, 強度レベルが高くなる ほど供試体の中心軸と荷重の重心位置の差は大きくなること がわかった。したがって、コンクリートの強度レベルが増大す るほど，供試体がズレることによって圧縮強度比が栋著に低下 する理由の一つは，供試体に作用する荷重の重心位置に起因す るものと考えられた。

（3）今回の実験の範囲では, JIS A 1108「コンクリートの圧縮試験 方法」に示される供試体設置位置の許容範囲内で圧縮強度試験 を行えば，いずれの強度領域のコンクリートであっても，ほぼ 中心に設置した場合と同等の圧縮強度が得られることがわか った。これより，JIS の範囲で実験を行えばほぼ正しい結果が 得られると考えられた。

（4）今回の実験の横ひずみ実測值を整理した結果, 供試体の中央部, 下端部近傍に比べ，上端部近傍は供試体のズレが大きくなるほ ど横ひずみが小さくなることが確認できた。この結果は，供試 体がズレることにより, 球座と接する供試体上端部の設置圧に よる拘束力が上がることを示唆していた。

\section{参考文献}

1）小山善行, 早川光敬, 陣内浩, 中村光男 : 超高強度コンクリート供試体の 載荷面の平面度と圧縮強度の関係に関する基礎的研究, 日本建築学会構造 系論文集，Vol.75，No.649，pp. 475-481，2010.3

2）鈴木澄江, 小山善行, 陣内 浩, 早川光敬 : 圧縮強度試験における荷重速 度がコンクリートの圧縮強度と変形性状に及ぼす影響に関する基礎的研 究, 日本建築学会構造系論文集, Vol. 74, No. 636, pp. 201-207, 2009.2

3）小山善行, 鈴木澄江, 早川光敬, 陣内浩 : 圧縮強度試験における荷重速度 と強度レベルがコンクリートの強度・変形性状に及ぼす影響, 日本コンク リート工学協会年次論文集 Vol. 31, No. 1, pp. 409-414, 2009

4）野口貴文, 友澤史紀 : 高強度コンクリートの圧縮強度試験結果に及ぼす試 験機球面座の挙動の影響, 日本建築学会構造系論文集, No. 478, pp. 9-17, 1995. 12

5）平岩 陸，谷川恭雄 : 偏心荷重を受けるコンクリートの破壊挙動に関する 解析的研究, 日本建築学会東海支部研究報告書, 第 46 号, pp. 81-84, 2008.2

6）寺内利恵子，渡邊悟士，黒岩秀介，陣内浩，山本佳城，並木哲：設計基淮 強度 $200 \mathrm{~N} / \mathrm{mm}^{2}$ の超高強度コンクリートの実用化に関する研究(その 2 実製 造設備による供試体レベルでの検討），日本建築学会大会学術講演梗概集 A, pp. 893-894, 2009. 8

7）日本建築学会 : 建築工事標準仕様書・同解説 JASS5 鉄筋コンクリート工事 付 18. JASS5 M-701：2005 高強度コンクリート用セメントの品質基準 附属書 3, p. 719, 2009.2

8) 日本建築学会:建築工事標準仕様書・同解説 JASS5 鉄筋コンクリート工事, p. $185,2009.2$

9）武藤清：鉄筋コンクリート構造物の塑性設計，丸善株式会社， 1964.8

10）六車熙，渡辺史夫，岩清水隆，光枝良：横補強による高強度コンクリー トのじん性改善に関する研究, 第 5 回コンクリート工学年次講演会講演論 文集，pp. 317-320，1983

（2011年10月 4 日原稿受理，2012年 2 月13日採用決定） 